\title{
Intergroup Contact, Intergroup Anxiety, and Attitudes towards the Opposing Group in Divided Society
}

\author{
Mimoza Telaku
}

AAB College, Pristina, Kosovo

\begin{abstract}
The negative attitudes and negative emotions play a key role in maintaining the hostilities between the groups of a divided society. Evidence suggests that intergroup contact can improve or worsen intergroup attitudes. The current study examined the mediating role of intergroup anxiety on quantity of interethnic contact and acculturation attitudes and emotional responses to contradictory conflict narratives in a divided society with a background of armed conflict in the past. The study was conducted among 202 Albanians and 239 Serbs in Kosovo. The results indicate that as more as they meet members of the opposing group the less they feel intergroup anxiety and the more they show acculturation attitudes towards the opposing group among both Albanians and Serbs. However, such mediating role of intergroup anxiety was not found on emotional responses to contradictory conflict narratives, except among Serbs who live in certain enclaves. The findings are discussed in terms of context, reconciliation, and maintenance of frozen conflict.
\end{abstract}

Keywords: contradictory conflict narratives, acculturation, intergroup anxiety, quantity of interethnic contact

\section{Introduction}

One of the main challenges of divided societies is facing the hostile attitudes between groups in conflict. Understanding the characteristics of the intergroup attitudes and intergroup contact in such contexts is important in reconciliation. The relation between these two constructs has been studied extensively in different contexts. However, the findings of these studies were contradictory. Several studies were conducted based on Allport's (1954) contact hypothesis. Some of these studies indicated that intergroup contact is positively related to positive attitudes towards the “other" group (e.g., Dixon et al., 2010; Laurence, 2020; Pettigrew \& Tropp, 2011;

Mimoza Telaku, AAB College, Rr. Elez Berisha, Nr.56 Zona Industriale Fushë Kosovë 10000 Pristina, Kosovo. E-mail: mimozatelaku@yahoo.com

Data collection for this research project was supported by the Foundation Open Society Institute (FOSI). 
Prestwich et al., 2008; Tropp et al., 2017; Yücel \& Psaltis, 2019; White et al., 2018). Other studies indicate that intergroup contact increases negative attitudes towards the "other" group (e.g., Dovidio et al., 2017; Hewstone \& Swart, 2011; Hodson \& Hewstone, 2013; Pettigrew \& Tropp, 2006; Pettigrew et al., 2011). Mainly, they measured intergroup attitudes in terms of prejudices and acculturation.

One of the constructs examined in terms of attitudes towards the opposing group regarding the conflict is perceptions of conflict narratives. These are narratives that provide justification, explanation, and rationalization for the outbreak and continuation of conflict (Bar-Tal, 2020). Acculturation is the other construct measured in such contexts. Several studies found that there are contradictions in the perceptions of collective narratives of conflict between groups in conflict (e.g., Ayalon \& Sagy, 2011; Mana et al., 2012; Sagy et al., 2002, 2011) and predominant endorsement of the separation strategy of acculturation among the ethnic or religious groups in conflict (e.g., Ayalon \& Sagy, 2011; Telaku \& Sagy, 2018).

Intergroup anxiety is an important factor in interactions between the groups in conflict and intergroup attitudes. The level of intergroup anxiety is higher among individuals who have had minimal previous contact (Stephan \& Stephan, 1985). It is recognized that contact between the groups in conflict can provoke greater intergroup hostility (Tropp, 2012) and therefore can increase intergroup anxiety.

Some studies have examined the relation of the intergroup contact and positive attitudes towards the "other" group mediated by the intergroup anxiety in the context with no background of conflict between groups (e.g., Islam \& Hewstone, 1993; Stephan \& Stephan, 1985). The present study examined the intergroup attitudes in a divided society context with a background of armed conflict in the past. It was focused on acculturation attitudes and emotions towards contradictory conflict narratives and their relation to quantity of interethnic contact and intergroup anxiety. Specifically, the acculturation attitudes and emotions towards contradictory conflict narratives were compared in relation to the quantity of interethnic contact with mediating role of intergroup anxiety.

\section{Background Information}

Albanians and Serbs in Kosovo are two ethnic groups in conflict. They were engaged in armed conflict during 1998 - 1999. The tensions between these two ethnic groups emerged with the abolition of Kosovo's autonomy in 1989. Serbian regime exercised systematic oppression towards Kosovo Albanians, which culminated with the armed conflict in 1998-1999 between Serbian forces and Albanian guerrillas (Kostovicova, 2005). From February 1998, through June 1999, $67(64 \%)$ of 105 deaths in the sample population were attributed to war-related trauma, corresponding to $12,000(95 \%$ CI $5,500-18,300)$ deaths in the total population (Spiegel \& Salama, 2000). North Atlantic Treaty Organization (NATO) launched air strikes against the Federal Republic of Yugoslavia. Almost one million 
Albanians fled their homes (United Nations High Commissioner for Refugees, 1999), whereas almost 200,000 Serbs and Roma fled Kosovo to Serbia and Montenegro (Tatham, 2009). Following the end of the armed conflict, the Serb community in Kosovo has been a target of murder, repeated threats, arson, and crop burning (Andrighetto et al., 2012).

Albanians and Serbs have different perceptions of the situational conflict (Nikolić, 2003). For example, Albanians view Serbs as aggressors, occupiers, and war criminals who deliberately sought a greater Serbia, and independence is seen as the only possible solution to these problems, while Serbs usually see Albanians as enemies who want to create a greater Albania at the expense of the Serbs (Romanych $\&$ Krumm, 2004). There are studies that indicate that there is a huge social distance between these two ethnic groups (e.g. Arënliu et al., 2013) and only 35\% of Serbs in Kosovo are ready to live in the same town with Albanians, and Albanians feel the same (UNDP Kosovo, 2013). The results of a survey conducted in 2019 in multiethnic municipalities in Kosovo indicate that $33.7 \%$ of Albanians and $37.9 \%$ of Serbs believe that relations of people of different ethnic groups are neutral; $10.4 \%$ of Albanians and 36.4\% of Serbs believe they are tense, and Serbs reported least interethnic contacts compared to other ethnic groups (only $46 \%$ of them reported they often or sometimes interact with members of other ethnic groups) (UNDP Kosovo, 2019).

After the end of the war in 1999, members of the Serb community displaced in certain localities formed Serb majority municipalities or enclaves. In the north of Kosovo (the north of Ibër river) there are four adjacent municipalities with a population consisting of $87 \%$ Serbs, $10 \%$ Albanians, and 3\% Bosnians (Organization for Security and Co-operation in Europe, 2018). These municipalities compose a compact region in terms of ethnicity. The rest of Serb localities are the enclaves scattered in the rest of Kosovo territory (the south of Ibër river). Due to these geographic differences, the present research analysed separately Serbs in the north of the Ibër river in Kosovo and Serbs in the south of the Ibër river in Kosovo.

\section{Collective Narratives}

Bruner (1990, p. 76) defines collective narratives as "social constructions that coherently interrelate a sequence of historical and current events; they are accounts of a community's collective experiences, embodied in its belief system and represent the collective's symbolically constructed shared identity." According to Salomon (2004, p. 274) "collective narratives are the comprehensive collection of stories, beliefs, aspirations, histories, and current explanations that a group holds about itself and about its surroundings. By necessity, the collective narratives of groups in conflict contradict each other and mirror each other, providing interpretations of events that negate those of the other side. Thus, whereas a group's collective narratives bolster the group's self-identity and justifies its role in the conflict, it, also, 
invalidates the other side's collective narrative and its role in the conflict: If "we" are right, "they" are surely wrong, and if "we" are victims, "they" are obviously perpetrators." Bar-Tal and Salomon (2006, p. 23) defined collective memory narrative as "a story that is biased, selective, and distorted, that omits certain facts, adds others that did not take place, changes the sequences of events, and purposely reinterprets events that did take place".

According to Bar-Tal (2020), "one major reason for the continuation of conflicts is the development of well-developed narratives that provide justification, explanation, and rationalization for their outbreak and feed their continuation. These conflict-supporting narratives are imparted to society members, and are institutionalized, maintained, and reinforced constantly, systematically, and continuously" (Bar-Tal, 2020, p. 37).

In the current study, the exploration of the contradictory conflict narratives is based on the model developed by Sagy et al. (2002), which was explored in different conflict contexts (e.g., Mana et al., 2012, 2015, 2019). The adopted model in the current study consists of empathy to in-group's conflict narratives and anger to opposing group's conflict narratives.

\section{Acculturation}

The concept of ethnicity captures the cultural background of an individual, reflecting the predominant values, attitudes, and expectations in which the individual has been raised (Whitbourne \& Whitbourne, 2011). Ethnic identity is one form of cultural identity and deals with how individuals and groups define and make sense of themselves, in terms of the ethnic group they belong to and a new ethnic group (Sam \& Berry, 2006). According to Berry (1993, p. 271) "the cultural and political context in which an individual develops and experiences his/her life can be a significant factor in the emergence and maintenance of ethnic behaviour, including person's ethnic identity." In all multicultural societies, cultural groups and their individual members must deal with the issue of how to acculturate (Berry \& Sam, 1997). Acculturation does not take place in a "vacuum" but at a specific time and place - a cultural context, which may include the sociopolitical background of the groups in contact as well as the reasons behind the contact (Sam \& Berry, 2006).

Berry (1990) proposed that acculturation is the "process by which individuals change, both by being influenced by contact with another culture and by being participants in the general acculturative changes underway in their own culture." The bidimensional model posits two dimensions; the first indicating the extent to which an individual has integrated into the new culture and the second, the extent to which he/she has retained elements of their original culture (Berry \& Kim, 1988). In other words, these dimensions are cultural maintenance (the extent to which cultural identity and characteristics are considered important by individuals and their maintenance strived for) and contact and participation (the extent to which 
individuals become involved in other cultural groups, or remain primarily among those of their own culture) (Berry, 1997). ${ }^{1}$

\section{Intergroup Anxiety}

Stephen and Stephen (1985) introduced the concept of intergroup anxiety. They define intergroup anxiety as a type of anxiety that people experience when anticipating or engaging in intergroup interaction. It is more specific than social anxiety because it is restricted to intergroup contexts. Affectively, intergroup anxiety is experienced as negative and aversive. People experiencing intergroup anxiety feel apprehensive, distressed, and uneasy. Intergroup anxiety is generally felt when anticipating future or experiencing actual contact with an out-group member (Stephen \& Stephen, 1985). Several studies indicate that intergroup interaction does elicit anxiety-related affect (e.g., Amodio, 2009; Britt et al., 1996; Littleford et al., 2005; Liu et al., 2010). There are studies that indicate the intergroup anxiety is positively related to negative attitudes towards the out-group (e.g., Berrenberg et al., 2002; Renfro et al., 2006; Stephan \& Stephan, 1989; Stephan et al., 2000, 1999, 1998; Van Zomeren et al., 2007). There are studies that indicate that believing the in-group and out-group have a history of conflict is positively correlated with intergroup anxiety (Cole \& Maxwell, 2003; Corenblum \& Stephan, 2001; Gibson, 2004; Hewstone et al., 2014; Islam et al., 1993; Paolini et al., 2006; Pettigrew \& Tropp, 2008; Stephan et al., 2002).

\section{Quantity of Interethnic Contact}

Quantity of interethnic contact relates to the frequency of direct interethnic encounters. Allport (1954) suggested that unfavourable out-group attitudes are due to a lack of information about the out-group, and that contact can thus reduce prejudice by providing opportunities to learn about the out-group. Higher intergroup contact has been shown to increase implicit attitudes (unconscious evaluations or feelings) towards out-groups (Prestwich et al., 2008) and to decrease levels of prejudice (Dixon et el., 2010). Tropp et al. (2017) found that contact of higher quality predicted more positive intergroup attitudes, trust, more positive perceptions of outgroup intentions in working toward peace, and greater engagement in reconciliation efforts. Similarly, Yücel and Psaltis (2019) found that the positive effect of intergroup contact on willingness for renewed cohabitation is mediated by both trust and prejudice. Even e-contact improved out-group attitudes via improved contact expectancies and reduced intergroup anxiety (White et al., 2018). Intergroup contact was found positively related to intergroup cohesion (Laurence, 2020). On the other hand, across a wide variety of contexts, Rovenpor et al. (2019) found that making

\footnotetext{
${ }^{1}$ In the following, cultural maintenance is mentioned as in-group acculturation, whereas contact and participation is mentioned as out-group acculturation.
} 
intergroup conflict salient increased the meaning people found in conflict and, in turn, increased support for conflict-perpetuating beliefs, ideologies, policies, and behaviours.

\section{Research Hypotheses}

Intergroup anxiety mediates the relation between quantity of interethnic contact and acculturation attitudes and emotions to contradictory conflict narratives.

Hypothesis 1. The influence of quantity of interethnic contact on out-group acculturation is mediated by intergroup anxiety.

Hypothesis 2. The relation between quantity of interethnic contact and emotions towards the contradictory conflict narratives is mediated by intergroup anxiety.

2.1. The influence of quantity of interethnic contact on empathy and anger towards the opposing group's contradictory conflict narratives is mediated by intergroup anxiety.

2.2. The influence of quantity of interethnic contact on empathy and anger towards the in-group's contradictory conflict narratives are mediated by intergroup anxiety.

\section{Method}

\section{Participants}

The total number of participants in this research is 441; 202 Albanians, 117 Serbs in the north of Ibër river, and 122 Serbs in the south of Ibër river. ${ }^{2}$ The samples were drawn in different localities throughout Kosovo.

\section{Table 1}

Demographic Characteristics of the Sample

\begin{tabular}{lcc}
\hline & \multicolumn{2}{c}{ Gender } \\
\hline & Male & Female \\
\cline { 2 - 3 } Albanians & $56.5 \%$ & $43.5 \%$ \\
Serbs in north & $53.0 \%$ & $47.0 \%$ \\
Serbs in south & $57.8 \%$ & $42.2 \%$ \\
\hline
\end{tabular}

\footnotetext{
${ }^{2}$ In this article I refer to Serbs who live in the north of Ibër river as "Serbs in the north" and Serbs who live in the south of Ibër river as "Serbs in the south".
} 
Telaku, M.:

Intergroup Anxiety and Attitudes

\begin{tabular}{lcccc}
\hline \multicolumn{5}{c}{ Age } \\
\hline & Mean & Median & & \\
\cline { 2 - 4 } Albanians & 33.83 & 30 & & \\
Serbs in north & 33.50 & 30 & & \\
Serbs in south & 34.96 & 31 & & \\
\hline & \multicolumn{4}{c}{ Education } \\
\hline & Primary & Secondary & Undergraduate & Postgraduate \\
\hline Albanians & $1.5 \%$ & $19.9 \%$ & $53.7 \%$ & $24.9 \%$ \\
Serbs in north & $0.9 \%$ & $43.6 \%$ & $47.9 \%$ & $7.7 \%$ \\
Serbs in south & $4.2 \%$ & $51.7 \%$ & $37.5 \%$ & $6.7 \%$ \\
\hline
\end{tabular}

\section{Measures}

The questionnaires were first drafted in English for the research project "Community Sense of Coherence and Openness toward the 'Other' in Intergroup Relations: The Case of Serbs and Albanians in Kosovo". Independent translators translated it to Albanian and Serbian. They were native speakers of Albanian and Serbian, respectively. The translations were independently back-translated to ensure the accuracy of the translations.

Contradictory Conflict Narratives Questionnaire was constructed based on the mainstream views of Albanians and Serbs concerning the armed conflict during 1998 - 1999 and events preceding and directly following this conflict. This questionnaire was developed based on the model of the collective narratives questionnaire developed by Sagy et al. (2002).

The contradictory conflict narratives of the ethnic groups in this research were gathered from five focus groups based on the method used by Srour et al. (2013). The focus groups were conducted in different areas in Kosovo. One focus group was conducted with only Albanian participants in an Albanian mono-ethnic locality. Another focus group was conducted with only Serb participants in a Serb monoethnic locality. Three focus groups were conducted with mixed participants in mixed Albanian and Serb localities. Each of these focus groups had both Albanian and Serb participants.

The contradictory conflict narratives questionnaire was constructed based on the contradictory conflict narratives gathered from these focus groups. The selection of the examined contradictory conflict narratives was based on two criteria: (1) the level of familiarity (i.e., the event was well known among both group members) and (2) the level of contradiction (i.e., the two groups hold opposing conflict narratives regarding the same event). Each event that participants discussed in focus groups constituted a set of conflict narratives with two views of the interethnic conflict: Albanian's view and Serb's view. The collected conflict narratives from focus groups were verified based on the contradictions for each set of conflict narratives. If the views within each set of conflict narratives were incongruent and opposing, they 
were included in the final questionnaire. Otherwise, they were excluded from the final questionnaire.

The final questionnaire of this research included seven sets of contradictory conflict narratives. Each set consisted of one conflict narrative of an Albanian ethnic group and another one of a Serb ethnic group regarding the same event within the interethnic conflict. Participants were presented first with their own ethnic group's conflict narrative and then with the opposing group's conflict narrative for each set of conflict narratives. For example, the questionnaire for Albanian participants first presented the conflict narrative of Albanians "Many Albanians believe that there are a lot of civilian war victims due to Serbian military and paramilitary forces operations" and then followed by the conflict narrative of Serbs "Many Serbs believe that there are a lot of civilian war victims due to the NATO bombing".

They were asked to indicate their degree of agreement and disagreement with statements about each contradictory conflict narrative. These statements concern empathy and anger. The degree of agreement and disagreement scaled from 1 (strongly disagree) to 5 (strongly agree). The Cronbach's $\alpha$ for empathy to in-group's conflict narratives was .68 among Albanians and .74 among Serbs, anger towards ingroup's conflict narratives was .81 among Albanians and .88 among Serbs, empathy to "other" group's conflict narratives was .75 among Albanians and .78 among Serbs, and anger towards “other" group's conflict narratives was .79 among Albanians and .84 among Serbs.

The Acculturation Attitudes Questionnaire was designed based on the Acculturation Questionnaire (Ayalon et al., 2011). Contextual and identity factors were considered in designing the questionnaire. The Acculturation Questionnaire (Ayalon et al., 2011) was designed for Arabs and Jews in Israel, whereas the acculturation attitudes questionnaire for the present study is designed for Albanians and Serbs in Kosovo. Items regarding the perception of ethnic group membership, participation in ethnic community activities, and ethnic pride. The questionnaire consists of two subscales: (1) the in-group acculturation subscale measures the dimension of preference for one's own group culture, which is equivalent to cultural maintenance, and (2) the out-group acculturation subscale measures the dimension of preference for the "other" group's culture, which is equivalent to contact and participation. Both dimensions measure acculturation attitudes as represented in several domains, i.e., friendship, neighbourhood, workplace, music, language, customs, ethnic community membership, participation in ethnic community events, and ethnic pride. There is a total of 16 items on this questionnaire. The in-group acculturation dimension has 9 items and the out-group acculturation has 7 items. The response to each item consists of a self-rated Likert scale ranging from 1 - Not at all true to 5-Very true. The Cronbach's $\alpha$ for the in-group acculturation subscale among Albanians is .92 and among Serbs is .90, and for the out-group acculturation subscale among Albanians is .79 and among Serbs is .83. 
Since the Kosovo society is divided and the Serb community lives in enclaves with limited opportunities for contact with the Albanian community, the acculturation was measured in terms of preferences how to interact with members of the opposing group rather than strategies as real behaviours or concrete plans how to interact with them.

Factorial analysis was conducted for the acculturation data. The Principal Component Analysis (PCA) using Promax (oblique rotation) indicated the presence of two stable factors. The first factor was identified as 'in-group acculturation' and the second was identified as 'out-group acculturation.' The significant negative correlation which was found between these two factors $(r=-.29)$ indicates that the bi-dimensional model has been preserved and the indexes are reliable.

\section{Table 2}

Principal Component Analysis of the Acculturation Dimensions

\begin{tabular}{lcc}
\hline No. Items & Factor 1 & Factor 2 \\
\hline In-group acculturation (attitudes towards the in-group) & & \\
1. I want to have more Albanian/Serb friends. & $\mathbf{8 2}$ & -.04 \\
2. I want to have more Albanian/Serb neighbours. & $\mathbf{. 6 6}$ & -.05 \\
3. I would like to work with Albanian/Serb colleagues. & $\mathbf{. 7 6}$ & -.16 \\
4. I like Albanian/Serbian music. & $\mathbf{. 9}$ & -.08 \\
5. I prefer to speak the Albanian/Serbian language. & $\mathbf{. 4 4}$ & .00 \\
6. I like Albanian/Serbian customs. & $\mathbf{. 7 5}$ & .07 \\
7. I see myself as member of the Albanian/Serb community. & $\mathbf{. 8 2}$ & .08 \\
8. I am proud of being Albanian/Serb. & $\mathbf{. 6 5}$ & .13 \\
9. I like to participate in activities of the Albanian/Serb & $\mathbf{. 7 7}$ & .08 \\
community. & & \\
\hline Out-group acculturation (attitudes towards the out-group) & .09 & $\mathbf{. 8 5}$ \\
10. I want to have more Serb/Albanian friends. & -.05 & $\mathbf{. 8 2}$ \\
11. I want to have more Serb/Albanian neighbours. & -.04 & $\mathbf{. 8 3}$ \\
12. I would like to work with Serb/Albanian colleagues. & -.12 & $\mathbf{. 6 7}$ \\
13. I like Serbian/Albanian music. & -.00 & $\mathbf{. 5 9}$ \\
14. I prefer to speak the Serbian/Albanian language. & .10 & $\mathbf{. 6 8}$ \\
15. I like Serbian/Albanian customs. & .09 & $\mathbf{. 7 4}$ \\
16. I like to participate in activities of the Serb/Albanian & \\
\hline community. &
\end{tabular}

The Intergroup Anxiety Scale was adopted from the Stephan's prejudice scale (Stephan \& Stephen, 1985). The adopted scale first presents the context "When I meet Albanians/Serbs I usually feel:" followed by the items of feelings: uneasy, nervous, threatened, uncertain, uncomfortable, and anxious. Each item has a 7-point scale ranging from 1 - not at all to 7 -very much.

The quantity of interethnic contact was measured by one item "I meet Albanians/Serbs"; (1) never, (2) rarely, (3) sometimes, (4) often, (5) very often. 


\section{Procedure}

The survey was conducted among Serbs and Albanians in Kosovo. The questionnaires were administered in the main streets of different localities. The research assistants were recruited from local communities. They approached the citizens on the streets and presented the aim of the research. They asked them to participate and told them that they could refuse. They also told them that if they want to participate, their anonymity would be assured. Each survey assistant waited until each participant had completed the questionnaire and helped him/her read it when any of the participants asked for that.

\section{Results}

\section{Preliminary Analysis}

Correlations were computed among all study variables. Spearman correlation was computed for the correlations between the quantity of interethnic contact and all other variables, whereas Pearson correlation was computed for the correlations between all variables, except intergroup ethnic contact. The findings indicate that 13 out of 28 correlations were statistically significant varying from $r(441)=-.10$ to -.38 and from $r(441)=.17$ to .32 .

\section{Table 3}

Correlations between the Study Variables

\begin{tabular}{|c|c|c|c|c|c|c|c|c|}
\hline Variables & 1 & 2 & 3 & 4 & 5 & 6 & 7 & 8 \\
\hline $\begin{array}{l}\text { 1. Quantity of } \\
\text { interethnic contact }^{\mathrm{a}}\end{array}$ & - & & & & & & & \\
\hline 2. Intergroup anxiety ${ }^{b}$ & $-.25^{* *}$ & - & & & & & & \\
\hline $\begin{array}{l}\text { 3. Empathy to in-group } \\
\text { conflict narratives }^{b}\end{array}$ & -.02 & -.06 & - & & & & & \\
\hline $\begin{array}{l}\text { 4. Anger to in-group } \\
\text { conflict narratives }^{b}\end{array}$ & $-.10^{*}$ & .06 & $-.18^{* *}$ & - & & & & \\
\hline $\begin{array}{l}\text { 5. Empathy to out-group } \\
\text { conflict narratives }^{b}\end{array}$ & -.04 & $-.12^{*}$ & $-.10^{*}$ & $.32^{* *}$ & - & & & \\
\hline $\begin{array}{l}\text { 6. Anger to out-group } \\
\text { conflict narratives }\end{array}$ & $.20^{* *}$ & .07 & $.25^{* *}$ & -.03 & $-.15^{* *}$ & - & & \\
\hline $\begin{array}{l}\text { 7. In-group } \\
\text { acculturation }^{\mathrm{b}}\end{array}$ & .02 & $.17^{* *}$ & $.19^{* *}$ & -.04 & $-.12^{*}$ & $.24^{* *}$ & - & \\
\hline $\begin{array}{l}\text { 8. Out-group } \\
\text { acculturation }^{\text {b }}\end{array}$ & .35 & $-.38^{* *}$ & -.04 & -.04 & $.17^{* *}$ & .05 & $-.17^{* *}$ & - \\
\hline
\end{tabular}

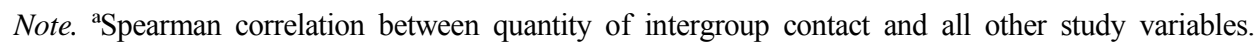
bPearson correlation between all study variables, except quantity of interethnic contact. ${ }^{*} p<.05 ;{ }^{* *} p<.01$. 
The results of the present study were analysed based on ethnicity and the geographic area of Serbs living in Kosovo. Therefore, there are three groups: Albanians, Serbs in the north, and Serbs in the south. Several statistical tests were conducted to test the differences of the three groups on each variable of the present study.

Kruskall Wallis $H$ test was conducted to test the differences in the level of quantity of interethnic contact between the three groups. The results indicate that there are significant differences in quantity of interethnic contact $\left(\chi^{2}(2)=54.02, p<\right.$ .01 ), with a median of 2 among Albanians, 2 among Serbs in the north, and 3 among Serbs in the south in the scale of 1 (never) to 5 (very often).

The Levene's test was conducted to test the homogeneity of variances of intergroup anxiety, emotional responses towards contradictory conflict narratives, and acculturation attitudes. The results indicate that there is no homogeneity of variances among the research variables, except anger to out-group conflict narratives.

\section{Table 4}

Test of Homogeneity of Variances for Research Variables Based on Ethnicity

\begin{tabular}{lrrrr}
\hline & $\begin{array}{c}\text { Levene } \\
\text { Statistic }\end{array}$ & $d f 1$ & $d f 2$ & $p$ \\
\hline Intergroup anxiety & 32.00 & 2.00 & 438.00 & .00 \\
\hline Empathy to in-group conflict narratives & 8.47 & 2.00 & 435.00 & .00 \\
Anger to in-group conflict narratives & 12.28 & 2.00 & 438.00 & .00 \\
Empathy to out-group conflict narratives & 9.62 & 2.00 & 438.00 & .00 \\
Anger to out-group conflict narratives & 1.19 & 2.00 & 438.00 & .31 \\
\hline In-group acculturation & 4.87 & 2.00 & 438.00 & .01 \\
Out-group acculturation & 3.80 & 2.00 & 438.00 & .02 \\
\hline
\end{tabular}

The Welch test was conducted to test the mean differences on research variables. The results indicate that there are significant mean differences on each research variable. Games-Howell post hoc test was conducted to identify the mean differences in all combinations of the groups in pairs of each research variable. The results indicate that there are significant mean differences of the groups on research variables among the groups. However, such differences were not significant on all sets of combinations. 


\section{Table 5}

Research Variables Means Comparisons Based On Ethnic Groups

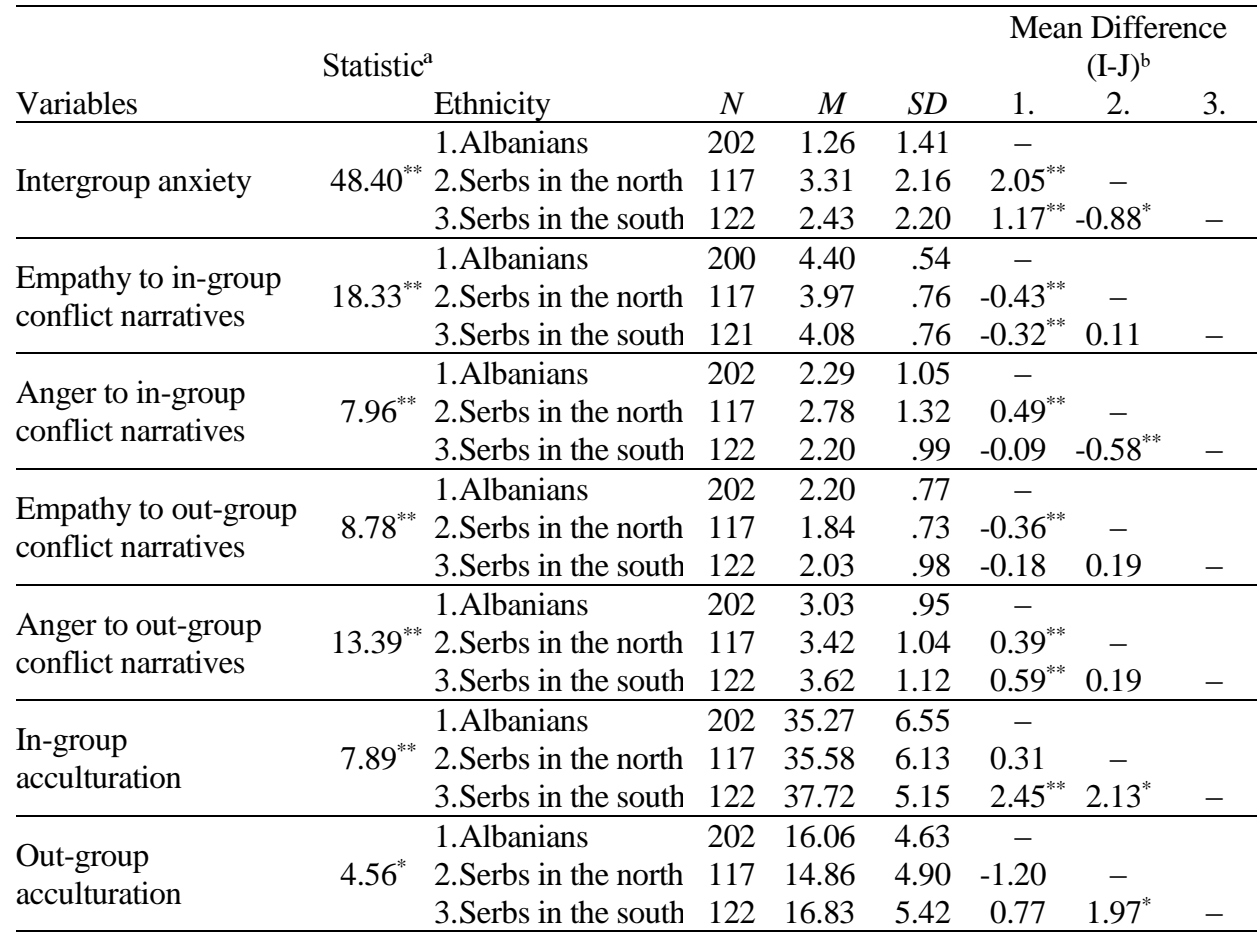

Note. ${ }^{\mathrm{a}}$ Welch test. Asymptotically F distributed. ${ }^{\mathrm{b}}$ Games-Howell Post Hoc test. ${ }^{*} p<.05 ;{ }^{* *} p<.01$.

\section{Mediation Effect of Intergroup Anxiety}

Due to the differences between the ethnic groups on each research variable, the analysis of the mediation effect of intergroup anxiety was conducted separately for each ethnic group. The mediation analysis included the identification of inconsistent mediation too. The results of the present study indicate that intergroup anxiety mediates the relation between quantity of interethnic contact and in-group acculturation, out-group acculturation, and empathy to out-group conflict narratives among three ethnic groups of this study.

The results indicate that intergroup anxiety mediates the relationship between quantity of interethnic contact and acculturation among Albanians. The quantity of interethnic contact is indirectly related to in-group acculturation through intergroup anxiety. As it is shown in the Table 6 the more members of the Albanian community contact the members of the Serb community the less they feel intergroup anxiety, $B=-0.45, S E=0.10, p<.001$. While controlling for quantity of interethnic contact, intergroup anxiety was found positively related to in-group acculturation, $B=1.47$, 
$S E=0.33, p<.01$. The direct relation of quantity of interethnic contact and in-group acculturation was not found significant, $B=0.23, S E=0.46, p=.61$. The results of the Sobel test indicate that there is significant mediation effect, $B=-0.66, S E=0.21$, $z=-3.18, p<.01$. The results also indicate that quantity of interethnic contact is indirectly related to out-group acculturation through intergroup anxiety. Intergroup anxiety was found negatively related to out-group acculturation while controlling for quantity of interethnic contact, $B=-0.68, S E=0.24, p<.01$. The direct relation of quantity of interethnic contact and out-group acculturation was found significant and positively related, $B=1.22, S E=0.33, p<.01$. The results of the Sobel test indicate that there is significant mediation effect, $B=0.30, S E=0.13, z=2.39, p=.02$. The finding supports the first hypothesis.

\section{Table 6}

Model Coefficients for Quantity of Interethnic Contact, Intergroup Anxiety, and Acculturation Attitudes Among Albanians

\begin{tabular}{|c|c|c|c|c|c|c|c|c|c|c|c|}
\hline \multirow[b]{3}{*}{ Antecedent } & \multicolumn{11}{|c|}{ Consequent } \\
\hline & \multicolumn{3}{|c|}{$\begin{array}{c}M \text { (Intergroup } \\
\text { anxiety) }\end{array}$} & \multicolumn{4}{|c|}{$\begin{array}{c}Y \text { (In-group } \\
\text { acculturation) }\end{array}$} & \multicolumn{4}{|c|}{$\begin{array}{l}Y \text { (Out-group } \\
\text { acculturation) }\end{array}$} \\
\hline & $B$ & $S E$ & $p$ & $B$ & $S$ & $E$ & $p$ & $B$ & $S E$ & & $p$ \\
\hline $\begin{array}{l}X \\
\text { (Interethnic } \\
\text { contact) }\end{array}$ & -0.45 & 0.10 & $<.01$ & 0.23 & 0. & 46 & .61 & 1.22 & 0.33 & & $<.01$ \\
\hline \multirow[t]{2}{*}{$\begin{array}{l}M \\
\text { (Intergroup } \\
\text { anxiety) }\end{array}$} & - & - & - & 1.47 & 0.3 & 33 & $<.01$ & -0.68 & 0.24 & & $<.01$ \\
\hline & $\begin{array}{r}R^{2} \\
F(1,18 \\
p \\
\end{array}$ & $\begin{array}{l}0.10 \\
=21 . \\
.01\end{array}$ & & $F(2$, & $\begin{array}{c}R^{2}= \\
188) \\
p<\end{array}$ & $\begin{array}{l}0.10 \\
=10 . \\
.01\end{array}$ & 42 & $F(2$, & $\begin{array}{l}R^{2}=0 \\
188)= \\
p<.\end{array}$ & $\begin{array}{l}.14 \\
=15.8 \\
01 \\
\end{array}$ & .83 \\
\hline \multirow{2}{*}{$\begin{array}{l}\text { Normal } \\
\text { theory test } \\
\text { for indirect } \\
\text { effect }\end{array}$} & & & & Effect & $S E$ & $z$ & $p$ & Effect & $S E$ & $z$ & $p$ \\
\hline & & & & -0.66 & 0.21 & -3.18 & $3<.01$ & 0.30 & 0.13 & 2.39 & 0.02 \\
\hline
\end{tabular}

Among Serbs in the north, the mediation results indicate that intergroup anxiety mediates the relation between the quantity of interethnic contact and empathy to outgroup conflict narratives and out-group acculturation attitudes as it is shown in Table 7 and Table 8. The more members of the Serb community in the north contact members of the Albanian community the less they feel intergroup anxiety, $B=-0.75$, $S E=0.18, p<.01$. While controlling for quantity of interethnic contact, intergroup anxiety was found negatively related to empathy to out-group conflict narratives, $B=-0.08, S E=0.03, p=.02$. The direct relation of quantity of interethnic contact and empathy to out-group conflict narratives was not found significant, $B=0.03$, $S E=0.07, p=.69$. The results of the Sobel test indicate that there is significant mediation effect, $B=0.06, S E=0.031, z=2.01, p=.04$. The finding partially 
supports the second hypothesis. Intergroup anxiety was also found negatively related to out-group acculturation while controlling for quantity of interethnic contact, $B=$ $-0.71, S E=0.21, p<.01$. The direct relation of quantity of interethnic contact and out-group acculturation was not found significant, $B=0.75, S E=0.44, p=.09$. The results of the Sobel test indicate that there is significant mediation effect, $B=0.53$, $S E=0.21, z=2.57, p=.01$. The finding supports the first hypothesis.

\section{Table 7}

Model Coefficients for Quantity of Interethnic Contact, Intergroup Anxiety, and Emotional Responses to Out-group Conflict Narratives among Serbs in North

\begin{tabular}{|c|c|c|c|c|c|c|c|c|c|c|}
\hline & \multicolumn{10}{|c|}{ Consequent } \\
\hline & \multicolumn{3}{|c|}{$\begin{array}{l}M \text { (Intergroup } \\
\text { anxiety) }\end{array}$} & \multicolumn{3}{|c|}{$\begin{array}{c}Y \text { (Empathy to } \\
\text { outgroup conflict } \\
\text { narratives) }\end{array}$} & \multicolumn{4}{|c|}{$\begin{array}{c}Y \text { (Anger to outgroup } \\
\text { conflict narratives) }\end{array}$} \\
\hline & $B$ & $S E$ & $p$ & $B$ & $S E$ & $p$ & $B$ & $S E$ & $p$ & \\
\hline $\begin{array}{l}X \text { (Interethnic } \\
\text { contact) }\end{array}$ & -0.75 & 0.18 & $<.01$ & 0.03 & 0.07 & .69 & 0.10 & 0.10 & .35 & \\
\hline \multirow[t]{2}{*}{$\begin{array}{l}M \text { (Intergroup } \\
\text { anxiety) }\end{array}$} & - & - & - & - .08 & 0.03 & .02 & 0.01 & 0.05 & .80 & \\
\hline & \multicolumn{3}{|c|}{$\begin{array}{c}R^{2}=0.13 \\
F(1,115)=16.66 \\
p<.01\end{array}$} & \multicolumn{3}{|c|}{$\begin{array}{c}R^{2}=0.06 \\
F(2,114)=3.71 \\
p=.03\end{array}$} & \multicolumn{4}{|c|}{$\begin{array}{c}R^{2}=0.01 \\
F(2,114)=0.45 \\
p=.64\end{array}$} \\
\hline \multirow{2}{*}{$\begin{array}{l}\text { Normal theory } \\
\text { test for } \\
\text { indirect effect }\end{array}$} & & & & Effect & $S E$ & $z \quad p$ & Effect & $S E$ & $z$ & $p$ \\
\hline & & & & 0.06 & 0.03 & 2.01 .04 & -0.01 & 0.04 & -0.24 & .81 \\
\hline
\end{tabular}

\section{Table 8}

Model Coefficients for Quantity of Interethnic Contact, Intergroup Anxiety, and Acculturation Attitudes Among Serbs in North

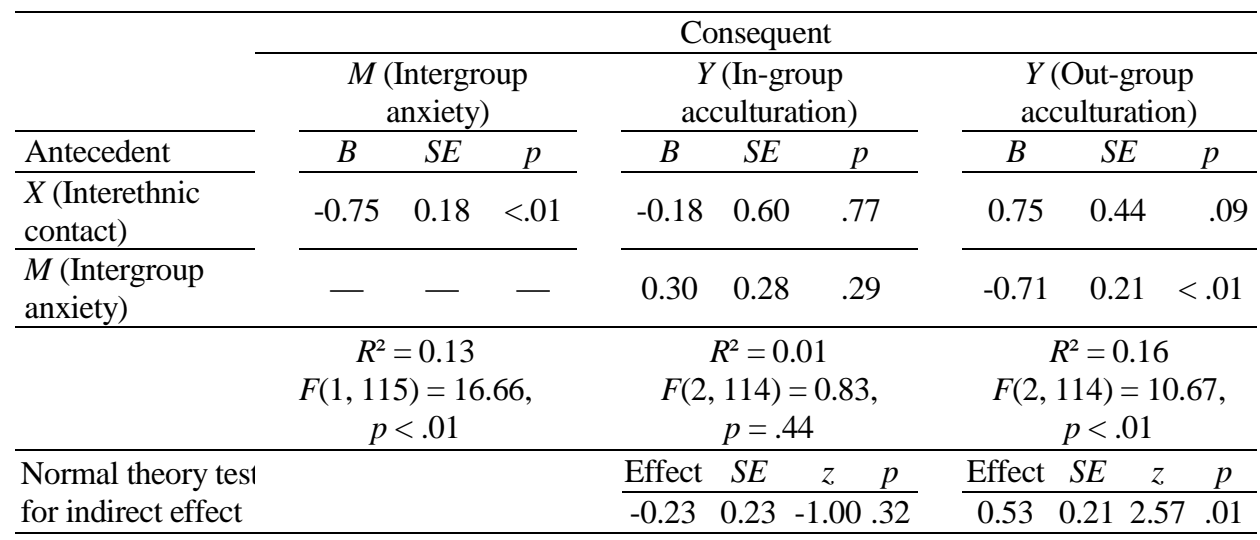


Among Serbs in the south, the only mediation effect was found between quantity of interethnic contact and out-group acculturation as it is shown in Table 9. The more members of Serb community in the south contact members of the Albanian community the less they feel intergroup anxiety, $B=-0.79, S E=0.17, p<.01$. Intergroup anxiety was found negatively related to out-group acculturation while controlling for quantity of interethnic contact, $B=-1.06, S E=0.20, p<.01$. The direct relation of quantity of interethnic contact and out-group acculturation was found significant and positively related, $B=1.17, S E=0.40, p<.01$. The results of the Sobel test indicate that there is significant mediation effect, $B=0.83, S E=0.24$, $z=3.46, p<.01$. The finding supports the first hypothesis.

\section{Table 9}

Model Coefficients for Quantity of Interethnic Contact, Intergroup Anxiety, and Acculturation Attitudes Among Serbs in the South

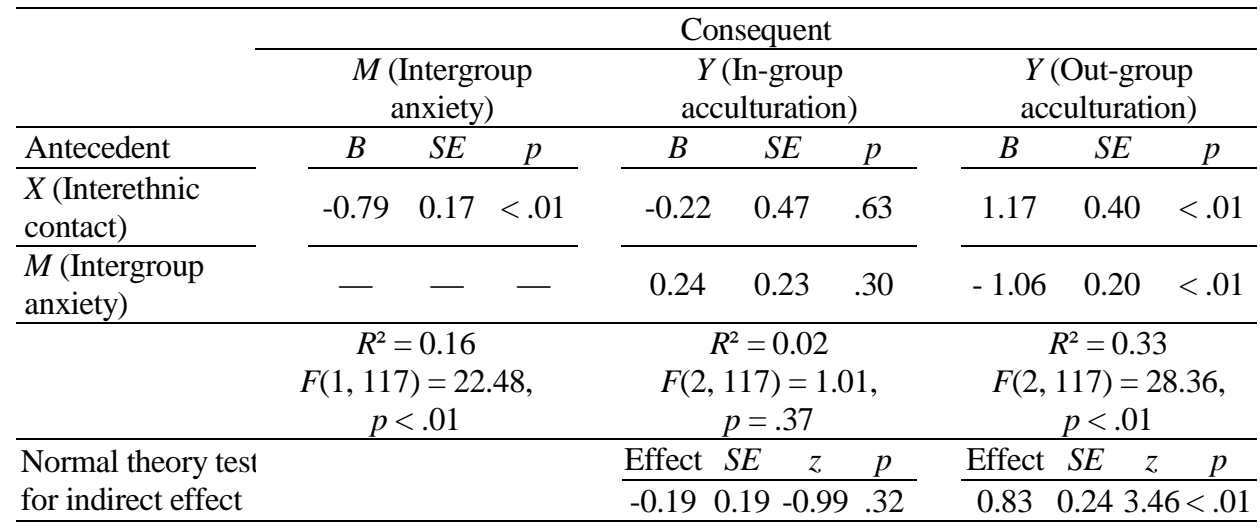

\section{Discussion}

The study explored the mediating role of intergroup anxiety on quantity of interethnic contact and attitudes towards the opposing group in a divided society context. The aim of the study was to examine whether there are relations of the quantity of interethnic contact and intergroup anxiety with both acculturation attitudes and emotional responses to conflict narratives. The findings of the study indicate that the quantity of interethnic contact decreases the intergroup anxiety and increases the acculturation towards the opposing group among the three groups in the study. However, the quantity of interethnic contact decreases the intergroup anxiety and increased the empathy towards the opposing group's conflict narratives only among Serbs in the north. 


\section{Figure 1}

Standardized Regression Coefficients for the Relationship Between Quantity of Interethnic Contact and Acculturation Attitudes and Emotional Responses to Conflict Narratives as Mediated by Intergroup Anxiety

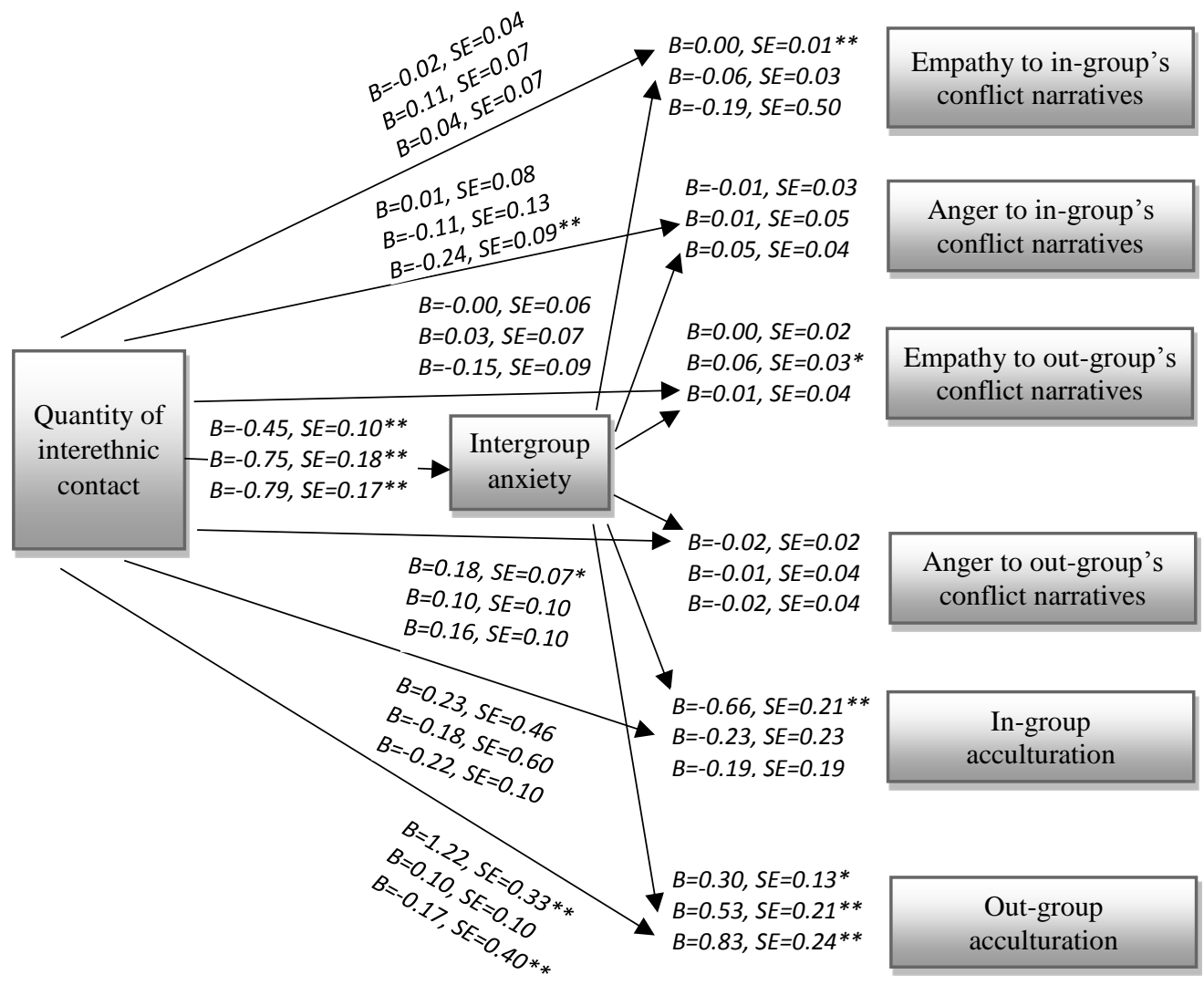

Note. The colour of the results indicate the groups of the study: black (Albanians -1 . row), dark grey (Serbs in north -2 . row), and light grey (Serbs in the south -3 . row). ${ }^{*} p<.05 ;{ }^{* *} p<.01$.

The findings are in accordance with the results of previous studies (e.g., Islam et al., 1993; Paolini et al., 2004; Swart et al., 2011; Voci \& Hewstone, 2003) and in contrary to other studies which indicate that intergroup interaction does elicit anxiety-related affect (e.g., Amodio, 2009; Britt et al., 1996; Littleford et al., 2005; Liu et al., 2010). The lower level of intergroup anxiety among those who interact more could be explained in terms of situational factors of the present interethnic conflict. The two ethnic groups were involved in armed conflict previously. However, the armed conflict was ended, and interethnic incidents are rare in the last decade. Members of the groups in conflict may have negative images of the members 
of the opposing group due to the armed conflict. However, the lack of interethnic incidents may make them feel safer as more as they meet members of the opposing group. When members of the opposing groups have successful interaction, their level of intergroup anxiety is likely to be reduced, as they come to realize they have nothing to fear from the out-group (Turner et al., 2007). This may lead to a greater willingness to build social ties and cooperate with members of the opposing group in aspects not related to interethnic conflict.

Regarding the beliefs of interethnic conflict, it seems that the beliefs are sustainable. The findings of the present study indicate that intensification of the interethnic contact and reduction of intergroup anxiety does not change the contradictory conflict narratives. In other words, each group in conflict has deeprooted beliefs regarding the conflict. The sustainability of these beliefs may be a potential to maintain the frozen conflict. An exemption is the Serb group living in the north of Kosovo. The results indicate that there is a relatively small effect size of the mediation effect of intergroup anxiety on interethnic contact and empathy to opposing group's conflict narratives. This implies the context, which needs to be explored for a better understanding of intergroup attitudes in conflict or post-conflict context.

The findings of the study have practical implications for reconciliation. First, the findings indicate that after the armed conflict, as more members of the opposing groups meet each other the less they feel uncomfortable meeting them. This would be a sufficient start in improving intergroup relations (Beelmann \& Heineman, 2014). Second, members of the groups in conflict might be willing to open to the opposing group in terms of culture when they have contact with them. However, the contacts with the members of the opposing group do not neutralize the divergences of beliefs and emotions towards the intergroup conflict. This may suggest that the efforts on improving intergroup relations should begin on nonconflictual aspects. Third, intergroup contact and intergroup anxiety are not as relevant in changing the viewpoints regarding the intergroup conflict as they are in increasing the willingness to interact culturally with them. This may indicate that changing the willingness to interact culturally with members of the opposing group does not reduce the intergroup contradictions. Therefore, it may maintain the frozen conflict. This may suggest that it is important to identify the underlying factors that could change the contradictory viewpoints of the conflict to contribute to sustainable peace.

\section{Conclusions}

The findings of the present study indicate that intergroup contact in post armed conflict is related to positive intergroup attitudes when the intergroup contact is accompanied by a decrease in intergroup anxiety. However, the positive intergroup attitudes are limited. In a post armed conflict context, groups in conflict may show acculturation towards the opposing group. However, they may not show more 
empathy towards the opposing group's conflict narratives, even if they interact with them. Therefore, they may sustain the beliefs of in group's conflict narratives.

\section{Limitations and Future Directions}

The study did not examine the experiences during the interethnic armed conflict. Those experiences might be linked to the attitudes towards the opposing group and the emotions they experience when interacting with them. Moreover, the existing situational factors may play a significant role in shaping the attitudes towards the opposing groups. In the present study, it is reflected through the emotions towards opposing groups' conflict narratives, which was found only among the Serbs in the north. However, the study lacks the evidence of such factors, which could potentially play a significant role on shaping the attitudes towards the opposing group after the end of armed conflict. Another important aspect, which needs to be explored, is the dispute settlement that terminates the armed conflict. Such settlements might play a significant role in shaping and maintaining the attitudes towards the opposing group.

\section{References}

Allport, G. W. (1954). The nature of prejudice. Addison-Wesley.

Amodio, D. M. (2009). Intergroup anxiety effects on the control of racial stereotypes: A psychoneuroendocrine analysis. Journal of Experimental Social Psychology, 45(1), 6067. https://doi.org/10.1016/j.jesp.2008.08.009

Andrighetto, L., Mari, S., Volpato, C., \& Behluli, B. (2012). Reducing competitive victimhood in Kosovo: The role of extended contact and common ingroup identity. Political Psychology, 33(4), 513-529. https://doi.org/-10.1111/j.1467-9221.2012.00887.x

Arënliu, A., Bërxulli, D., \& Haskuka, M. (2013). Social distance in terms of demographic features - Kosovo population study. Iliria International Review, 3(1), 296-302. https://doi.org/10.21113/iir.v3i1.113

Ayalon, A., \& Sagy, S. (2011). Acculturation attitudes and perceptions of collective narratives: The case of Israeli-Arab youth. Youth and Society, 43, 819-844. https://doi.org/10.1177/0044118X11411150

Bar-Tal, D. (2020). Conflict supporting narratives and the struggle over them. In A. Srour \& A. Mana (Eds.), Collective narratives in intractable conflict: The case of the Israeli and Palestinian societies (pp. 36-60). Cambridge Scholars Publishing.

Bar-Tal, D., \& Salomon, G. (2006). Israeli-Jewish narratives of the Israeli-Palestinian conflict: Evolution, contents, functions, and consequences. In I. R. Rotberg (Ed.), Israeli and Palestinian narratives of conflict - History's double helix (pp. 19-46). Indiana University Press. 
Beelmann, A., \& Heineman, K. S. (2014). Preventing prejudice and improving intergroup attitudes: A meta-analysis of child and adolescent training programs. Journal of Applied Developmental Psychology, 35(1), 10-24. https://doi.org/10.1016/j.appdev.2013.11.002

Berrenberg, J. L., Finaly, K. A., Stephan, W. G., \& Stephan, C. (2002). Prejudice toward people with cancer or AIDS: Applying the integrated threat model. Journal of Applied Biobehavioral Research, 7(2), 75-86. https://doi.org/10.1111/j.1751-9861.2002. tb00078.x

Berry, J. W. (1990). Psychology of acculturation: Understanding individuals moving between cultures. In R. W. Brislin (Ed.), Applied cross-cultural psychology (pp. 232-253). Sage Publications, Inc.

Berry, J. (1993). Ethnic identity in plural societies. In M. E. Bernal \& G. P. Knight (Eds.), Ethnic identity: Formation and transmission among Hispanics and other minorities (pp. 271-296). State University of New York Press.

Berry, J. W. (1997). Immigration, acculturation and adaptation. Applied Psychology: An International Review, 46(1), 5-34. https://doi.org/10.1111/j.1464-0597.1997.tb01087.x

Berry, J. W., \& Kim, U. (1988). Acculturation and mental health. In P. R. Dasen, J. W. Berry, \& N. Sartorius (Eds.), Health and cross-cultural psychology: Toward applications (pp. 207-236). Sage Publications, Inc.

Berry, J. W. \& Sam, D. L. (1997). Acculturation and adaptation. In J. W. Berry, M. H. Segall, \& C. Kagitcibasi (Eds.), Handbook of cross-cultural psychology: Social behaviour and applications (Vol. 3, pp. 291-326). Allyn \& Bacon.

Britt, T. W., Boniecki, K. A., Vescio, T. K., Biernat, M., \& Brown, L. M. (1996). Intergroup anxiety: A person $\times$ situation approach. Personality and Social Psychology Bulletin, 22(11), 1177-1188. https://doi.org/10.1177/01461672962211008

Bruner, J. (1990). Acts of meaning. Harvard University Press.

Cole, D. A., \& Maxwell, S. E. (2003). Testing mediational models with longitudinal data: Questions and tips in the use of structural equation modeling. Journal of Abnormal Psychology, 112(4), 558-577. https://doi.org/10.1037/0021-843X.112.4.558

Corenblum, B., \& Stephan, W. G. (2001). White fears and native apprehensions: An integrated threat theory approach to intergroup attitudes. Canadian Journal of Behavioral Science / Revue Canadienne des Sciences du Comportement, 33(4), 251268. https://doi.org/10.1037/h0087147

Dixon, J., Durrheim, K., Tredoux, C., Tropp, L., Clack, B., \& Eaton, L. (2010). A paradox of integration interracial contact, prejudice reduction, and perceptions of racial discrimination. Journal of Social Issues, 66(2), 401-416. https://doi.org/10.1111/j.15404560.2010.01652.x

Dovidio, J. F., Love, A., Schellhaas, F. H., \& Hewstone, M. (2017). Reducing intergroup bias through intergroup contact: Twenty years of progress and future directions. Group Processes \& Intergroup Relations, 20(5), 606-620. https://doi.org/10.1177/ 1368430217712052 
Gibson, J. L. (2004). Overcoming apartheid: Can truth reconcile a divided nation? Politikon: South African Journal of Political Studies. 31(2), 129-155. https://doi.org/10.1080/ 0258934042000280698

Hewstone, M., \& Swart, H. (2011). Fifty-odd years of intergroup contact: From hypothesis to integrated theory. British Journal of Social Psychology, 50(3), 374-386. https://doi.org/10.1111/j.2044-8309.2011.02047.x

Hewstone, M., Lolliot, S., Swart, H., Myers, E., Voci, A., Al Ramiah, A., \& Cairns, E. (2014). Intergroup contact and intergroup conflict. Peace and Conflict: Journal of Peace Psychology, 20(1), 39-53. https://doi.org/10.1037/a0035582

Hodson, G., \& Hewstone, M. (2013). Introduction: Advances in intergroup contact. In G. Hodson \& M. Hewstone (Eds.), Advances in intergroup contact (pp. 3-20). Psychology Press.

Islam, M. R., \& Hewstone, M. (1993). Dimensions of contact as predictors of intergroup anxiety, perceived out-group variability, and out-group attitude: An integrative model. Personality and Social Psychology Bulletin, 19(6), 700-710. https://doi.org/10.1177/ 0146167293196005

Kostovicova, D. (2005). Kosovo: The politics of identity and space. Routledge.

Laurence, J. (2020). Cohesion through participation? Youth engagement, interethnic attitudes, and pathways of positive and negative intergroup contact among adolescents: A quasi-experimental field study. Journal of Ethnic and Migration Studies, 46(13), 2700-2722. https://doi.org/10.1080/1369183X.2019.1700787

Littleford, L. N., Wright, M. O., \& Sayoc-Parial, M. (2005). White students' intergroup anxiety during same-race and interracial interactions: A multimethod approach. Basic and Applied Social Psychology, 27(1), 85-94. https://doi.org/10.1207/ s15324834basp2701_9

Liu, L. A., Chua, C. H., \& Stahl, G. K. (2010). Quality of communication experience: Definition, measurement, and implications for intercultural negotiations. Journal of Applied Psychology, 95(3), 469-487. https://doi.org/10.1037/a0019094

Mana, A., Sagy, S., Srour, A., \& Mjally-Knani, S. (2012). Perceptions of collective narratives and identity strategies: The case of Palestinian Muslims and Christians in Israel. Mind \& Society, 11(2), 165-182. https://doi.org/10.1007/s11299-012-0108-y

Mana, A., Sagy, S., Srour, A., \& Mjally-Knani, S. (2015). On both sides of the fence: Perceptions of collective narratives and identity strategies among Palestinians in Israel and in the West Bank. Mind \& Society, 14(1), 57-83. https://doi.org/10.1007/s11299014-0159-3

Mana, A., Srour, A., \& Sagy, S. (2019). A sense of national coherence and openness to the "other's" collective narrative: The case of the Israeli-Palestinian conflict. Peace and Conflict: Journal of Peace Psychology, 25(3), 226-233. https://doi.org/10.1037/ pac0000391 
Nikolić, L. (2003). Ethnic prejudices and discrimination: The case of Kosovo. In F. Bieber \& Ž. Daskalovski (Eds.), Understanding the war in Kosovo (pp. 51-74). Frank Cass Publishers.

Organization for Security and Co-operation in Europe. (2018). Municipal profiles - 2018. OSCE Mission in Kosovo.

Paolini, S., Hewstone, M., Cairns, E., \& Voci, A. (2004). Effects of direct and indirect crossgroup friendships on judgments of Catholics and Protestants in Northern Ireland: The mediating role of an anxiety-reduction mechanism. Personality and Social Psychology Bulletin, 30(6), 770-786. https://doi.org/10.1177/0146167203262848

Paolini, S., Hewstone, M., Voci, A., Harwood, J., \& Cairns, E. (2006). Intergroup contact and the promotion of intergroup harmony: The influence of intergroup emotions. In R. Brown \& D. Capozza (Eds.), Social identities: Motivational, emotional, and cultural influences (pp. 209-238). Psychology Press.

Pettigrew, T. F., \& Tropp, L. R. (2006). A meta-analytic test of intergroup contact theory. Journal of Personality and Social Psychology, 90(5), 751-783. https://doi.org/10.1037/ 0022-3514.90.5.751

Pettigrew, T. F., \& Tropp, L. R. (2008). How does intergroup contact reduce prejudice? Metaanalytic tests of three mediators. European Journal of Social Psychology, 38(6), 922 934. https://doi.org/10.1002/ejsp.504

Pettigrew, T. F., \& Tropp, L. R. (2011). Essays in social psychology. When groups meet: The dynamics of intergroup contact. Psychology Press.

Pettigrew, T. F., Tropp, L. R., Wagner, U., \& Christ, O. (2011). Recent advances in intergroup contact theory. International Journal of Intercultural Relations, 35(3), 271-280. https://doi.org/10.1016/j.ijintrel.2011.03.001

Prestwich, A., Kenworthy, J. B., Wilson, M., \& Kwan-Tat, N. (2008). Differential relations between two types of contact and implicit and explicit racial attitudes. British Journal of Social Psychology, 47(4), 575-588. https://doi.org/10.1348/014466607X267470

Renfro, C. L., Duran, A., Stephan, W. G., \& Clason, D. L. (2006). The role of threat in attitudes toward affirmative action and its beneficiaries. Journal of Applied Social Psychology, 36(1), 41-74. https://doi.org/10.1111/j.0021-9029.2006.00003.x

Romanych, M. J., \& Krumm, K. (2004). Tactical information operations in Kosovo. Military Review, 84(5), 56-61.

Rovenpor, D. R., O'Brien, T. C., Roblain, A., De Guissmé, L., Chekroun, P., \& Leidner, B. (2019). Intergroup conflict self-perpetuates via meaning: Exposure to intergroup conflict increases meaning and fuels a desire for further conflict. Journal of Personality and Social Psychology, 116(1), 119-140. https://doi.org/10.1037/pspp0000169

Sagy, S., Adwan, S., \& Kaplan, A. (2002). Interpretations of the past and expectations for the future among Israeli and Palestinian youth. American Journal of Orthopsychiatry, 72(1), 26-38. https://doi.org/10.1037/0002-9432.72.1.26 
Sagy, S., Ayalon, A., \& Diab, K. (2011). Perceptions of the narrative of the "other" among Arab and Jewish adolescents in Israel: Between peace talks and violent events. Intercultural Education, 22(2), 1991-206. https://doi.org/10.1080/14675986.2011. 567077

Salomon, G. (2004). A narrative-based view of coexistence education. Journal of Social Issues, 60(2), 273-287. https://doi.org/10.1111/j.0022-4537.2004.00118.x

Sam, D. L., \& Berry, J. W. (Eds.). (2006). The Cambridge handbook of acculturation psychology. Cambridge University Press. https://doi.org/10.1017/CBO9780511489891

Spiegel, P. B., \& Salama, P. (2000). War and mortality in Kosovo, 1998-99: An epidemiological testimony. Lancet, 355(9222), 2204-2209. https://doi.org/10.1016/ S0140-6736(00)02404-1

Srour, A., Sagy, S., Mana, A., \& Mjally-Knani, S. (2013). Collective narratives as indicators of examining intergroup relations: The case of Muslims and Christians in Israel. International Journal of Conflict Management, 24(3), 231-244. https://doi.org/10. 1108/IJCMA-10-2012-0072

Stephan, C. W., Stephan, W. G., Demitrakis, K. M., Yamada, A. M., \& Clason, D. L. (2000). Women's attitudes toward men: An integrated threat theory approach. Psychology of Women Quarterly, 24(1), 63-73. https://doi.org/10.1111/j.1471-6402.2000.tb01022.x

Stephan, W. G., \& Stephan, C. W. (1985). Inter-group anxiety. Journal of Social Issues, 41(3), 157-175. https://doi.org/10.1111/j.1540-4560.1985.tb01134.x

Stephan, W. G., \& Stephan, C. W. (1989). Antecedents of intergroup anxiety in Asian Americans and Hispanic Americans. International Journal of Intercultural Relations, 13(2), 203-219. https://doi.org/10.1016/0147-1767(89)90006-0

Stephan, W. G., Boniecki, K. A., Ybarra, O., Bettencourt, A., Ervin, K. S., Jackson, L. A., \& Renfro, C. L. (2002). The role of threats in racial attitudes of Blacks and Whites. Personality and Social Psychology Bulletin, 28(9), 1242-1254. https://doi.org/10.1177/ 01461672022812009

Stephan, W. G., Ybarra, O., \& Bachman, G. (1999). Prejudice toward immigrants: An integrated threat theory. Journal of Applied Social Psychology, 29(11), 2221-2237. https://doi.org/10.1111/j.1559-1816.1999.tb00107.x

Stephan, W. G., Ybarra, O., Martinez, C., Schwarzwald, J., \& Tur-Kaspa, M. (1998). Prejudice toward immigrants to Spain and Israel: An integrated threat theory analysis. Journal of Cross-Cultural Psychology, 29(4), 559-576. https://doi.org/10.1177/ 0022022198294004

Swart, H., Hewstone, M., Christ, O., \& Voci, A. (2011). Affective mediators of intergroup contact: A three-wave longitudinal study in South Africa. Journal of Personality and Social Psychology, 101(6), 1221-1238. https://doi.org/10.1037/a0024450

Tatham, A. F. (2009). Enlargement of the European Union. Kluwer Law International. 
Telaku, M., \& Sagy, S. (2018). Perceptions of collective narratives and acculturation attitudes: The case of Serbs and Albanians in Kosovo. In L. Gardner Feldman, R. Barash, \& S. Goda (Eds.), Societies in transition. The former Soviet Union and east central Europe between conflict and reconciliation (pp. 211-224). Vandenhoeck \& Ruprecht.

Tropp, L. (2012). Understanding and responding to intergroup conflict: Toward an integrated analysis. In L. Tropp (Ed.), The Oxford handbook of intergroup conflict (pp. 3-10). Oxford University Press.

Tropp, L. R., Hawai, D. R., O'Brien, T. C., Gheorghiu, M., Zetes, A., \& Butz, D. A. (2017). Intergroup contact and the potential for post-conflict reconciliation: Studies in Northern Ireland and South Africa. Peace and Conflict: Journal of Peace Psychology, 23(3), 239249. https://doi.org/10.1037/pac0000236

Turner, R. N., Crisp, R. J., \& Lambert, E. (2007). Imagining intergroup contact can improve intergroup attitudes. Group Processes \& Intergroup Relations, 10(4), 427-441. https://doi.org/10.1177/1368430207081533

UNDP Kosovo. (2013). Public Pulse Report -VI. Prishtinë/Pristina: UNDP Kosovo.

UNDP Kosovo. (2019). Public Pulse analysis 2019: Reconciliation and coexistence in Kosovo: perceptions of Kosovo ethnic communities. Prishtinë/Priština: UNDP.

United Nations High Commissioner for Refugees. (1999). Report of the United Nations high commissioner for refugees, 1999. Retrieved from http://www.unhcr.org

Van Zomeren, M., Fischer, A. H., \& Spears, R. (2007). Testing the limits of tolerance: How intergroup anxiety amplifies negative and offensive responses to out-group-initiated contact. Personality and Social Psychology Bulletin, 33(12), 1686-1699. https://doi.org/10.1177/0146167207307485

Voci, A., \& Hewstone, M. (2003). Intergroup contact and prejudice toward immigrants in Italy: The mediational role of anxiety and the moderational role of group salience. Group Processes \& Intergroup Relations, 6(1), 37-52. https://doi.org/10.1177/ 1368430203006001011

Whitbourne, S. K., \& Whitbourne, S. B. (2011). Adult development and aging: Biopsychosocial perspectives (4th ed.). Wiley.

White, F. A., Turner, R. N., Verrelli, S., Harvey, L. J., \& Hanna, J. R. (2018). Improving intergroup relations between Catholics and Protestants in Northern Ireland via Econtact. European Journal of Social Psychology, 49(2), 429-438. https://doi.org/10. 1002/ejsp. 2515

Yücel, D., \& Psaltis, C. (2019). Intergroup contact and willingness for renewed cohabitation in Cyprus: Exploring the mediating and moderating mechanisms. Group Processes and Intergroup Relations, 23(4), 578-597. https://doi.org/10.1177/1368430219845053 


\title{
Međugrupni kontakt, međugrupna anksioznost i stavovi prema suprotstavljenoj skupini u podijeljenome društvu
}

\begin{abstract}
Sažetak
Negativni stavovi i negativne emocije imaju ključnu ulogu u održavanju neprijateljstava među skupinama podijeljenoga društva. Prema dosadašnjim nalazima međugrupni kontakt može poboljšati ili pogoršati međugrupne stavove. Provedeno istraživanje provjerilo je medijatorsku ulogu međugrupne anksioznosti na količinu međuetničkih kontakata i akulturacijskih stavova te emocionalne odgovore na kontradiktorne narative sukoba u podijeljenome društvu s poviješću oružanih sukoba. U istraživanju provedenome na Kosovu sudjelovala su 202 Albanca te 239 Srba. Rezultati i kod Albanaca i kod Srba pokazuju da što se sudionici više susreću s pripadnicima protivničke skupine, to manje osjećaju međugrupnu anksioznost i više pokazuju akulturacijske stavove prema protivničkoj skupini. Međutim, takva medijatorska uloga međugrupne anksioznosti nije pronađena za emocionalne odgovore na kontradiktorne narative sukoba, osim među Srbima koji žive u određenim enklavama. O nalazima istraživanja raspravlja se u okvirima konteksta, pomirenja i održavanja zamrznutoga sukoba.
\end{abstract}

Ključne riječi: kontradiktorni konfliktni narativi, akulturacija, međugrupna anksioznost, količina međuetničkoga kontakta

Primljeno: 25. 5. 2020. 